\title{
Zinc transport proteins in plasma
}

\author{
BY J. K. CHESTERS AND MARIE WILL \\ Rowett Research Institute, Bucksburn, Aberdeen AB2 9SB
}

(Received 30 June 1980 - Accepted 24 February 1981)

1. Both albumin and transferrin have been suggested as carriers of zinc in plasma. Their relative importance in $\mathrm{Zn}$ transport was therefore investigated as a preliminary to a study of the rates of passage of $\mathrm{Zn}$ through plasma.

2. The apparent $\log$ stability zonstant for $\mathrm{Zn}$ binding to human apotransferrin at $\mathrm{pH} 7.4$ was estimated to be approximately 5.9 which is substantially lower than previous reports of 7.0 for the corresponding value for $\mathrm{Zn}$ binding to albumin (Giroux \& Henkin, 1972).

3. When the relative abilities of human albumin and apotransferrin to compete for $\mathrm{Zn}$ with low-molecular-weight chelators were compared at the :ame relative concentrations of these proteins as are found in plasma, albumin retained substantially more $\mathrm{Zn}$ than transferrin.

4. It seems likely that albumin acts as the major transport protein for $\mathrm{Zn}$ in plasma of most species, $\mathrm{Zn}$ also being present firmly bound to $\alpha_{2}$-macroglobulin.

5. In porcine plasma or serum however, there were three major Zn-binding proteins, two of which were probably albumin and $\alpha_{2}$-macroglobulin. The nature of the third component remains unknown but it appeared to have a molecular weight of between $100000-140000$, it was precipitated by $2.2 \mathrm{M}$-ammonium sulphate and by $150 \mathrm{~g}$ polyethylene glycol/1.

6. There were no significant differences in $\mathrm{Zn}$ distribution in plasma of porcine blood obtained from the aorta, the posterior vena cava or from the hepatic portal vein but use of heparin as an anticoagulant altered the normal pattern of distribution of $\mathrm{Zn}$ in Flasma.

In the plasma of most spesies approximately two thirds of the zinc present is bound to albumin and one third to $\alpha_{2}$-macroglobulin (Himmelhoch et al. 1966; Parisi \& Vallee, 1970; Giroux, 1975). In addition a small proportion is present in low-molecular-weight form. However, various reports had suggested that transferrin rather than albumin might be the physiologically-important Z'n carrier (Boyett \& Sullivan, 1970; Evans \& Winter, 1975). In man, both the total concen:ration of $\mathrm{Zn}$ in plasma and its distribution between the major protein complexes have been shown to vary following a range of imposed stresses (Vikbladh, 1951; Hallbook \& Hedelin, 1977). Similar changes have been observed in experimental animals (Pekarek \& Beisel, 1969; Corrigall et al. 1976; Whitenack et al. 1978). The work reported here was part of a programme to study the stress-induced alterations in $\mathrm{Zn}$ flux which accompany these changes in plasma $\mathrm{Zn}$ concentration and to investigate their physiological significance (C'hesters \& Will, 1981). The present paper reports investigations of the nature of the transport form of $\mathrm{Zn}$ in plasma which were carried out before the studies of $\mathrm{Zn}$ flux mentioned previously.

\section{EXPERIMENTAL}

\section{Materials}

Human apotransferrin, human and porcine albumin (fraction V), N-(2-hydroxyethyl)iminodiacetic acid, iminodiacetic acid, nitrilotriacetic acid and polyethylene glycol 6000 were obtained from Sigma Chenical Co., London; histidine from Cambrian Chemicals Ltd, Croydon, Surrey; and heparin from Evans Medical Ltd, Liverpool. All radioisotopes were supplied by the Radiochemical Centre, Amersham, Bucks. Cellulose acetate strips (Sephraphore III) were purchased from Gelman Hawksley Ltd, Northampton.

Porcine albumin was purified before use by continuous flow electrophoresis in $0.1 \mathrm{M}$ Tris-acetate buffer pH 8.3 using the apparatus described by Hannig (1961). The major 
albumin containing fractions were pooled, dialysed three times against 10 vol. distilled water and freeze dried. Small samples of the purified albumin were then iodinated by the chloramine T method of Bolton (1977).

\section{Blood samples}

Porcine blood was obtained from gilts weighing $30-50 \mathrm{~kg}$ which had been fitted with catheters terminating in the abdominal aorta or in some instances in the posterior vena cava or in the hepatic portal vein (Scott \& McIntosh, 1975). Other samples were obtained from the jugular of sheep, cattle and red deer, the heart of rats or from the veins of human volunteers.

Plasma was obtained by centrifugation of blood to which had been added heparin $(100 \mathrm{U} / \mathrm{ml}$ final concentration) or sodium fluoride $(0.24 \mathrm{M})$ as anticoagulants. Samples for serum were allowed to clot overnight at room temperature before centrifugation.

\section{Estimation of the apparent stability constant of Zn-transferrin}

Binding of $\mathrm{Zn}$ to human transferrin results in an alteration in the ultra-violet absorption of the protein. The difference spectrum of $\mathrm{Zn}$-transferrin $v$. apo-transferrin showed absorption maxima at 245 and $295 \mathrm{~nm}$ and a minimum at $275 \mathrm{~nm}$. These values are in close agreement with those found by Nagy \& Lehrer (1972) and Tan \& Woodworth (1969) and attributed by them to ionization of a tyrosine residue during binding of $\mathrm{Zn}$. Changes in absorption at $245 \mathrm{~nm}$ were therefore used to monitor the competition for $\mathrm{Zn}$ between transferrin and a range of chelators of known affinity for $\mathrm{Zn}$.

Human apotransferrin ( $4 \mathrm{mg}$ ) dissoved in $2.5 \mathrm{ml}$ of $0.02 \mathrm{M}$-sodium bicarbonate containing $0.15 \mathrm{M}$-sodium chloride (buffer $\mathrm{A}$ ) was placed in a $10 \mathrm{~mm}$ path-length cuvette and gassed with air-carbon dioxide $(95: 5, \mathrm{v} / \mathrm{v})$ to $\mathrm{pH} 7 \cdot 4$. Serial additions of $\mathrm{Zn}\left(5 \mu \mathrm{l} 3 \mathrm{mM}-\mathrm{ZnSO}_{4} \cdot 7 \mathrm{H}_{2} \mathrm{O}\right)$ were made to the solution which was re-gassed and the increase in absorbance at $245 \mathrm{~nm}$ $\left(+\Delta A_{245}\right)$ was read against apo-transferrin after each addition. After five additions the transferrin approached saturation and serial additions $(5 \mu \mathrm{l})$ were then made of a competing chelator and $-\Delta A_{245}$ was determined. All measurements were carried out at $37^{\circ}$.

Using the information obtained from the initial additions of $\mathrm{Zn}, \Delta \mathrm{A}_{\mathbf{2 4 5}}$ was plotted against the total $\mathrm{Zn}$ present and this relationship was used to determine the ionic plus transferrinbound $\mathrm{Zn}$ after each addition of the chelator. The amount of $\mathrm{Zn}$ in either mono- or di-complexes with the chelator was then obtained by difference. From a knowledge of the stability constants of these complexes and the equations below, the concentration of ionic $\mathrm{Zn}^{2+}$ was calculated for each concentration of the chelator (L).

$$
\begin{gathered}
{\left[\mathrm{Zn}^{2+}\right]=\frac{[\mathrm{ZnL}]}{K_{s}[\mathrm{~L}]}=\frac{\left[\mathrm{ZnL}_{2}\right]}{\beta[\mathrm{L}]^{2}}} \\
{[\mathrm{~L}]=[\Sigma \mathrm{L}]-[\mathrm{ZnL}]-2\left[\mathrm{ZnL}_{2}\right]}
\end{gathered}
$$

$[\mathrm{ZnL}]+\left[\mathrm{ZnL}_{2}\right]$ is the total concentration of chelator-bound $\mathrm{Zn}, \Sigma \mathrm{L}$ is the total amount of chelator added, $L$ is the concentration of free chelator and $K_{\delta}$ and $\beta$ are apparent stability constants of the complexes at $\mathrm{pH} 7 \cdot 4$. Since the same concentration of ionic $\mathrm{Zn}^{2+}$ was in equilibrium with the $\mathrm{Zn}$ bound to transferrin the following relationships could be used to estimate the apparent stability constant of the Zn-binding sites of transferrin $\left(K_{T f}\right)$.

$$
K_{T f}=\frac{[\mathrm{Zn} T f]}{\left[\mathrm{Zn}^{2+}\right][T f]}=\frac{[\Sigma \mathrm{Zn}]-\left[\mathrm{Zn}^{2+}\right]}{\left[\mathrm{Zn}^{2+}\right]([\Sigma T f]-[\mathrm{Zn} T f])}=\frac{[\Sigma \mathrm{Zn}]-\left[\mathrm{Zn}^{2+}\right]}{\left[\mathrm{Zn}^{2+}\right]\left([\Sigma T f]-[\Sigma \mathrm{Zn}]-\left[\mathrm{Zn}^{2+}\right]\right)}
$$

where $\Sigma \mathrm{Zn}$ is the total $\mathrm{Zn}$ either free or bound to transferrin and $\Sigma T f$ is the total concentration of binding sites on transferrin either free or complexed with $\mathrm{Zn}$. A mean ( $\pm \mathrm{SE}$ ) 
was then calculated from the individual estimates of $K_{T f}$ obtained after each addition of the chelator.

Where available, apparent stability constants for the chelators at $\mathrm{pH} 7.4$ were taken from Giroux \& Henkin (1972) to facilitate comparison of results. In other cases they were calculated from the values of $\log$ stability constants and pKa given by Sillen \& Martell (1964, 1971). Human serum transferrin was assumed to have a molecular weight of 77000 (Mann et al. 1970) and to possess tiwo identical Zn-binding sites per molecule (Nagy \& Lehrer, 1972).

\section{Relative Zn-binding affinities of albumin and transferrin}

Human apotransferrin ( $4 \mathrm{mg}$ ) or human albumin $(40 \mathrm{mg}$ ) was dissolved in $4 \mathrm{ml}$ buffer $A$ in a test tube. To this was added $30 \mu 1^{65} \mathrm{Zn}$ containing $0.82 \mu \mathrm{g} \mathrm{Zn}(1.35 \mu \mathrm{Ci} / \mu \mathrm{g})$ and an appropriate amount of a chelator dissolved in less than $50 \mu \mathrm{l}$ water. After gassing with air-carbon dioxide $(95: 5, \mathrm{v} / \mathrm{v})$ to give a $\mathrm{pH}$ of 7.4 the mixture was left at $37^{\circ}$ for $45 \mathrm{~min}$ to equilibrate and then ultrafiltered in situ at $37^{\circ}$ by suction through a 'Pellicon' membrane with 10000 nominal-molecular-weight limit (Immersible Molecular Separator; Millipore UK Ltd, London). Since these filters were found to have a significant affinity for $\mathrm{Zn}$ the filtrate was returned to the protein residue and the mixture re-gassed and re-filtered until all components were in equilibrium with a common concentration of ionic $\mathrm{Zn}^{2+}$. The relative affinities of the low-molecular-weight chelator and the protein for $\mathrm{Zn}$ were then assessed by expressing the filterable $\mathrm{Zn}$ as a proportion of the sum of the filterable and protein-bound $\mathrm{Zn}$.

\section{Gel filtration}

Samples of serum or plasma $(5 \mathrm{ml})$ were supplemented with $0.15 \mu \mathrm{Ci}{ }^{65} \mathrm{Zn}(0.8-1.4 \mu \mathrm{Ci} / \mu \mathrm{g})$ and with approximately $0.03 \mu \mathrm{Ci}^{125}$ I-labelled porcine albumin for subsequent identification of the distribution of albumin between fractions. The samples were left at room temperature for $5 \mathrm{~h}$ and were then loadeit onto an $800 \times 26 \mathrm{~mm}$ column of Sephadex G-100. The material was eluted with $0.02 \mathrm{M}$-Tris- $\mathrm{HCl}, \mathrm{pH} 7 \cdot 8$, containing $0.15 \mathrm{M}$ sodium chloride and collected in $5 \mathrm{ml}$ fractions. These were counted for ${ }^{125} \mathrm{I}$ and ${ }^{65} \mathrm{Zn}$ in a gamma counter; their absorbance was measured at $280 \mathrm{~nm}$ and then after acidification with hydrochloric acid they were analysed for $\mathrm{Zn}$ and copper by atomic absorption (Chesters \& Will, 1978). In a few instances, ${ }^{59} \mathrm{Fe}(0.02 \mu \mathrm{g}$ ard $0.25 \mu \mathrm{Ci})$ was added to plasma along with the ${ }^{65} \mathrm{Zn}$ and ${ }^{125}$ I-labelled albumin, the ${ }^{58} \mathrm{Fe}$ serving as a label for transferrin. Even in the presence of all three isotopes differential ccounting allowed satisfactory estimation of the quantities of each of the individual isotopes present. However Sephadex G-100 was found to have an appreciable affinity for $\mathrm{Zn}$ which resulted in substantial exchange between $\mathrm{Zn}$ bound to the column matrix and that in the sample. To minimize this problem, samples of radioactive plasma were initially passeci through the column to waste until the over-all specific activity of the $\mathrm{Zn}$ in the eluate was within $5 \%$ of that in the plasma.

In certain other experiments, instead of using plasma, the initial samples were prepared by dissolving individual proteins, either albumin $(40 \mathrm{mg} / \mathrm{ml})$ or apotransferrin $(4 \mathrm{mg} / \mathrm{ml})$ or a mixture of the two, in buffer $\mathbf{A}$. These were then supplemented with radioactive materials and chromatographed as described for plasma.

\section{RESULTS}

The binding of $\mathrm{Zn}$ to transfeirrin as assessed by $\Delta \mathrm{A}_{\mathbf{2 4 5}}$ indicated that the apparent log stability constant $\left(\log K_{8}\right)$ of the $\mathrm{Zn}$-binding sites was approximately 5.9 (Table 1 ). When the balance between free and bound $\mathrm{Zr}$. was determined by ultrafiltration of a solution of transferrin and $\mathrm{Zn}$, the calculated value of $\log K_{s}$ was 5.93. The $\mathrm{Zn}$-binding affinities of albumin and transferrin were then compared at physiologically relevant concentrations and the proportions of $\mathrm{Zn}$ rendered ultrafiltrable by addition of chelator was always substantially higher with transferrin than with albumin (Table 2). 
Table 1. Apparent log stability constant of the zinc-binding sites of transferrin determined from changes in absorption at $245 \mathrm{~nm}$ when $\mathrm{Zn}$ was bound to transferrin in the presence of varying concentrations of competing chelators

(Mean values with their standard errors of five estimates obtained on each of two occasions)

\begin{tabular}{lcc}
\hline \hline & \multicolumn{2}{c}{$\begin{array}{c}\text { Apparent log stability constant } \\
\text { of Zn-transferrin }\end{array}$} \\
\cline { 2 - 3 } Chelator & Mean & SE \\
\hline Glycine & 5.88 & 0.02 \\
Histidine & 5.85 & 0.03 \\
Iminodiacetic acid & 5.92 & 0.05 \\
\hline \hline
\end{tabular}

Table 2. Effect of addition of a competing low-molecular-weight chelator on the percentage of $\mathrm{Zn}$ which was ultrafilterable in solutions of albumin or transferrin

Percentage of $\mathrm{Zn}$ ultrafilterable (\%)

\begin{tabular}{lccc}
\hline \hline Chelator & $(\mu \mathrm{M})$ & $\begin{array}{c}\text { Albumin } \\
(10 \mathrm{mg} / \mathrm{ml})\end{array}$ & $\begin{array}{c}\text { Transferrin } \\
(1 \mathrm{mg} / \mathrm{ml})\end{array}$ \\
\hline Histidine & 200 & $5 \cdot 2$ & $39 \cdot 4$ \\
N-(2-hydroxyethyl) & 10 & $17 \cdot 1$ & $76 \cdot 1$ \\
iminodiacetic acid & 200 & $11 \cdot 8$ & $62 \cdot 8$ \\
Iminodiacetic acid & 5 & $18 \cdot 5$ & $85 \cdot 6$ \\
\hline
\end{tabular}

Chromatography of mixed preparations of ${ }^{65} \mathrm{Zn}$, ${ }^{125}$ I-labelled albumin and transferrin bearing trace quantities of ${ }^{59} \mathrm{Fe}$ on Sephadex G-100 failed to separate the proteins sufficiently to allow estimation of the proportions of $\mathrm{Zn}$ bound to albumin and transferrin. When chromatographed individually ${ }^{65} \mathrm{Zn}$-albumin produced coincident peaks of ${ }^{65} \mathrm{Zn}$ and absorbance at $280 \mathrm{~nm}$ whereas ${ }^{65} \mathrm{Zn}$ applied as $\mathrm{Zn}$-transferrin became bound to the column and eluted only slowly. None of the ${ }^{85} \mathrm{Zn}$ eluted along with the transferrin.

Gel filtration of porcine plasma on Sephadex G-100 produced a $\mathrm{Zn}$-distribution profile (Fig. 1a) which differed markedly from that previously reported for human serum and confirmed in the present study (Fig. 1 b). The proportion of $\mathrm{Zn}$ present in the peak at fraction no. 31 was greatly reduced and a third $\mathrm{Zn}$-binding component was present centred on fraction no. 26. The possible presence in other species of the $\mathrm{Zn}$-binding component at fraction no. 26 was investigated but chromatography of serum or fluoride-treated plasma f:om sheep, cattle, deer and rats as well as man failed to demonstrate any significant concentration of $\mathrm{Zn}$ at fraction no. 26. Within the species investigated this component was therefore of major importance only in the pig. $\left(\mathrm{NH}_{4}\right)_{2} \mathrm{SO}_{4}$ fractionation of porcine serum followed by gel chromatography showed that the $\mathrm{Zn}$-binding material at fraction no. 26 was precipitated by $2.2 \mathrm{M}-\left(\mathrm{NH}_{4}\right)_{2} \mathrm{SO}_{4}$ and was absent from the albumin fraction remaining soluble at this salt concentration. Similarly this unidentified $\mathrm{Zn}$-binding compound was precipitated by treatment of serum with polyethylene glycol 6000 at $150 \mathrm{~g} / \mathrm{l}$ (Chesters \& Will, 1981) but was absent from the supernatant fraction which contained albumin. When the material found in fractions 25-39 was concentrated by ultra-filtration and re-applied to the column, there was a substantial loss of $\mathrm{Zn}$ and ${ }^{65} \mathrm{Zn}$ from fraction no. 26 and the only residual $\mathrm{Zn}$ in the high-molecular-weight region co-chromatographed with albumin. 

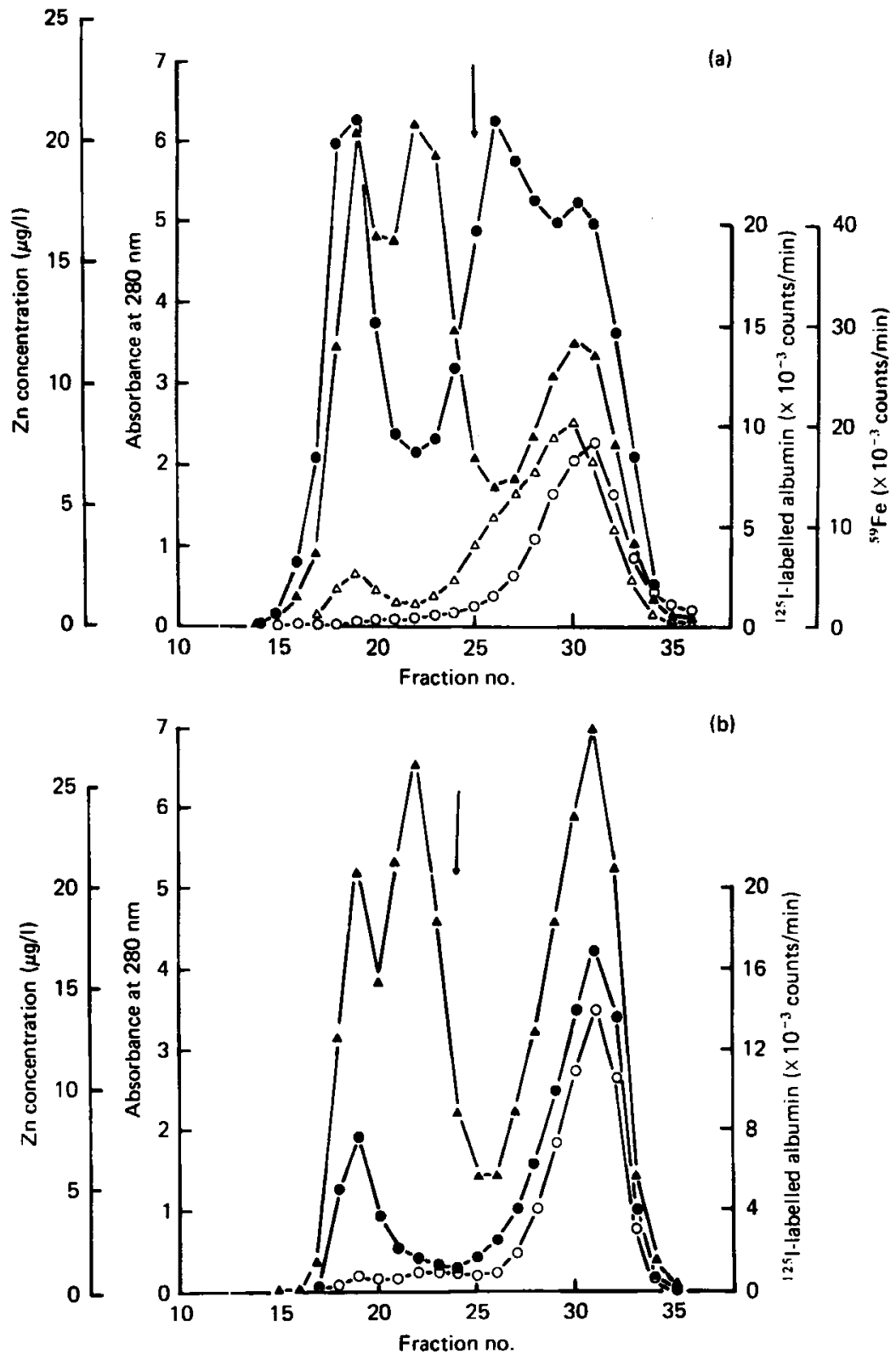

Fig. 1. Chromatography of (a) porcine plasma and (b) human serum on Sephadex G-100. $\mathrm{Zn}$ concentration $(\mathbf{O}-\mathrm{O})$, absorbance at $280 \mathrm{~nm}\left(\mathbf{\Delta - \Delta )}{ }^{125}\right.$ l-labelled albumin $(\mathrm{O}-\mathrm{O}){ }^{59} \mathrm{Fe}$ $(\triangle-\Delta)$. $\downarrow$. Position of the peak concentration of caeruloplasmin.

Plasma for the previous investigations was obtained from pigs with arterial catheters. However, comparable samples were also obtained from both venous and hepatic portal blood of pigs. When these samples were chromatographed on Sephadex G-100, no differences were found in the distribution of $\mathrm{Zn}$ in plasma from any of these sources. Furthermore, the pattern of distribution of $\mathrm{Zn}$ between fractions was similar when either porcine serum or fluoride-reated plasma was applied to the column. In contrast, with 


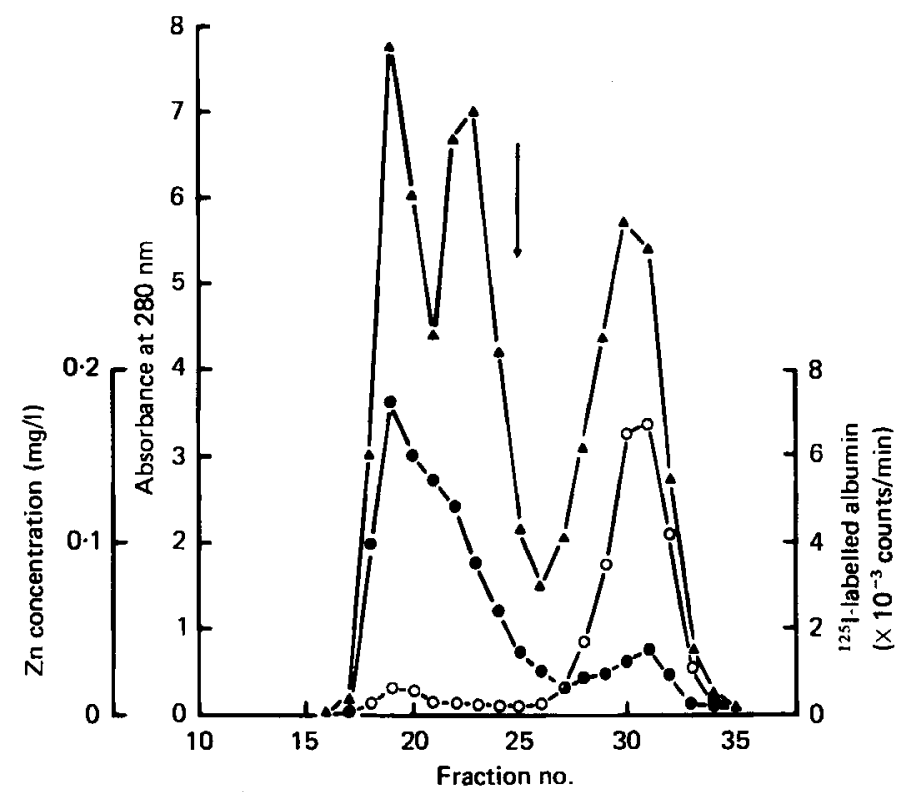

Fig. 2. Chromatography of heparinized porcine plasma on Sephadex G-100. Zn concentration (O-C), absorbance at $280 \mathrm{~nm}(\mathbf{\Delta}-\mathbf{A}),{ }^{125}$ I-labelled albumin $(\mathrm{O}-\mathrm{O})$. $\downarrow$, Position of the peak concentration of caeruloplasmin. Heparin was present at $100 \mathrm{I} . \mathrm{U} . / \mathrm{ml}$ in the sample applied to the column.

plasma which had been heparinized the distribution of $\mathrm{Zn}$ was markedly altered by a major shift of $\mathrm{Zn}$ into the region of fraction nos. 21-22, reduction in $\mathrm{Zn}$ at fraction no. 31 and disappearance of that at fraction no. 26 (Fig. 2).

\section{DISCUSSION}

As early as $1951, \mathrm{Zn}$ in human serum was shown to be largely bound to protein, two-thirds being loosely attached to one protein and one-third more strongly bound to another (Vikbladh, 1951). Subsequent studies have shown that these proteins were albumin and $\alpha_{2}$-macroglobulin respectively (Himmelhoch et al. 1966; Parisi \& Vallee, 1970; Giroux, 1975). However, Boyett \& Sullivan (1970) reported $\mathrm{Zn}$ to be present also in a transferrin fraction following electrophoretic separation of plasma proteins. More recently, Evans \& Winter (1975) reported that $70 \%$ of newly absorbed ${ }^{65} \mathrm{Zn}$ in portal plasma of rats was bound to transferrin and that even in peripheral plasma a substantial proportion was still present on this protein. Evans (1976) also showed that with a plasma membrane preparation from duodenal mucosa which had been labelled with ${ }^{65} \mathrm{Zn}$ in vivo, addition of apo-transferrin was more effective in removing ${ }^{85} \mathrm{Zn}$ than was albumin.

Taken together these previous studies suggested an important role for transferrin in $\mathrm{Zn}$ transport through plasma. There are however several reasons for questioning this suggestion. A re-examination of the paper of Boyett \& Sullivan (1970) indicated that in contrast to the authors' summary, none of the four $\mathrm{Zn}$-binding factors which they demonstrated co-electrophoresed with transferrin. Furthermore, in the investigations of $\mathrm{Zn}$ in portal blood by Evans \& Winter (1975), heparinised plasma was used and the transferrin fraction was found to chromatograph on Sephadex G-150 well in advance of albumin. In contrast the present studies with both human and porcine proteins separated on Sephadex G-100 (Fig. 1) and studies of rat plasma by Smith $e t$ al. (1978) using Sephadex G-200 have indicated that transferrin and albumin do not separate under chromatographic conditions 
similar to those used by Evans \& Winter (1975). It is possibly significant that heparinized plasma was used for the later investigations since use of porcine plasma which had been heparinized (Fig. 2) resulted in artifactual binding of $\mathrm{Zn}$ to a component with an elution characteristic on Sephade: similar to the fraction described by Evans \& Winter (1975) as $\mathrm{Zn}$-transferrin. Also in contast to the latter studies, no differences were detected in the pattern of $\mathrm{Zn}$-binding by porcine plasma of arterial, venous or hepatic-portal origin.

The present studies have indicated a $\log K_{s}$ for the $\mathrm{Zn}$-binding sites of transferrin of approximately 5.9. Under similar conditions, Giroux \& Henkin (1972) found that the log $K_{8}$ of the $1: 1 \mathrm{Zn}$-albumin complex was approximately $7 \cdot 0$. Since albumin is generally present in plasma in tenfold molar excess over transferrin, it seems unlikely that an appreciable proportion of $\mathrm{Zn}$ could remain on transferrin in plasma. The chelator competition studies reported here and those published recently by Charlwood (1979) further confirm that the equilibrium of $\mathrm{Zn}$ between transferrin and albumin is such that very little $\mathrm{Zn}$ will be present on transferrin when the two proteins are present together in the proportions found in plasma. Finally perfusion studies with rat intestinal preparations have shown that addition of albumin to the vascular perfusion medium was highly effective in mediating the uptake of $\mathrm{Zn}$ into the medium and that saturation of serum in the perfusate with iron failed to inhibit $\mathrm{Zn}$ uptake (Smith et al. 1978). The present evidence suggests therefore that in most species albumin is the maior transport protein for $\mathrm{Zn}$ in plasma, that one third of the $\mathrm{Zn}$ is bound to $\alpha_{2}$-macroglobulin and that $\mathrm{Zn}$-binding to transferrin is quantitatively insignificant.

The present studies have shown that porcine plasma in contrast to that of other species contains another component which binds about one-third of the $\mathrm{Zn}$ present, this change resulting almost entirely from a reduction in the proportion of $\mathrm{Zn}$ on albumin. The nature of this extra component (fraction no. 26) which so far appears to be restricted to porcine plasma remains unknown. Its behaviour on Sepahadex G-100 suggests a molecule of 100000-140000 molecular weight and it precipitated with the globulins when plasma was fractionated either with $\left(\mathrm{NH}_{4}\right)_{2} \mathrm{SO}_{4}$ or with polyethylene glycol. It eluted appreciably sooner than transferrin on Sephaclex G-100 but attempts to purify the fraction obtained from gel chromatography by rechromatography even on the same column resulted in loss of both $\mathrm{Zn}$ and ${ }^{65} \mathrm{Zn}$ from the region of fraction no. 26. The same applied even when anaerobic conditions were used to avcid the possiblity of destruction of oxygen-sensitive ligand groups.

There have been two frevious reports of metal-binding proteins from plasma with properties similar to the material in fraction no. 26. Himmelhoch et al. (1966) found a $\mathrm{Zn}$-binding protein in hurran serum which was precipitated with $2.2 \mathrm{M}\left(\mathrm{NH}_{4}\right)_{2} \mathrm{SO}_{4}$, had a molecular weight of approximately 120000 and migrated with the albumins on electrophoresis. Furthermore, this protein was also unstable after separation by gel chromatography. Strangely no such protein has since been reported in human serum. More recently Nandedkar $e$ t al. (1974) isclated from rabbit plasma a Co-binding protein with a molecular weight of 120000 . This was immunoelectrophoretically identical with albumin and was postulated to be a dimer of it but the authors were unable to generate the monomer from it by reduction. No such fraction has been seen in the present experiments when purified porcine albumin has been chromatographed on Sephadex G-100 in the presence of $\mathrm{Zn}$. The nature of the material in fraction no. 26 requires further investigation.

The authors wish to thank Dr D. V. Rayner and Mr J. Suttie for providing samples of blood from the portal vein of pigs and from red deer and Dr F. W. White for cannulating pigs. 


\section{REFERENCES}

Bolton, A. E. (1977). Radioiodination Techniques. Amersham, England: Radiochemical Centre.

Boyett, J. D. \& Sullivan, J. F. (1970). Metabolism 19, 148.

Charlwood, P. A. (1979). Biochim. biophys. Acta 581, 260.

Chesters, J. K. \& Will, M. (1978). Br. J. Nutr. 39, 297.

Chesters, J. K. \& Will, M. (1981). Br. J. Nutr. 46, 119.

Corrigall, W., Dalgarno, A. C., Ewen, L. A. \& Williams, R. B. (1976). Vet. Rec. 99, 396.

Evans, G. (1976). Proc. Soc. exp. Biol. Med. 151, 775.

Evans, G. \& Winter, T. W. (1975). Biochem. biophys. Res. Commun. 66, 1218.

Giroux, E. L. (1975). Biochem. Med. 12, 258.

Giroux, E. I. \& Henkin, R. I. (1972). Biochim. biophys. Acta 273, 64.

Hallbook, T. \& Hedelin, H. (1977). Br. J. Surg. 64, 271.

Hannig, K. (1961). Z. analyt. Chem. 181, 244.

Himmelhoch, S. R., Sober, H. A., Vallee, B. L., Peterson, E. A. \& Fuwa, K. (1966). Biochemistry, N.Y. 5, 2523.

Mann, K. G., Fish, W. W., Cox, A. C. \& Tanford, C. (1970). Biochemistry, N.Y. 9, 1348.

Nagy, B. \& Lehrer, S. S. (1972). Archs Biochem. Biophys. 148, 27.

Nandedkar, A. K. N., Hong, M. S. \& Friedberg, F. (1974). Biochem. Med. 9, 177.

Parisi, A. F. \& Vallee, B. L. (1970). Biochemistry, N.Y. 9, 2421.

Pekarek, R. S. \& Beisel, W. R. (1969). Appl. Microbiol. 18, 482.

Scott, D. \& McIntosh, G. H. (1975). Q. Jl. exp. Physiol. 60, 131.

Sillen, L. G. \& Martell, A. E. (1964). Spec. Publs chem. Soc. 17.

Sillen, L. G. \& Martell, A. E. (1971). Spec. Publs. chem. Soc. 25.

Smith, K. T., Failla, M. L. \& Cousins, R. J. (1978). Biochem. J. 184, 627.

Tan, A. T. \& Woodworth, R. C. (1969). Biochemistry, N.Y. 8, 3711.

Vikbladh, I. (1951). Scand. J. clin. Lab. Invest. 3, Suppl. 2.

Whitenack, D. L., Whitehair, C. K. \& Miller, E. R. (1978). Am. J. vet. Res. 39, 1447. 